\title{
The BeAuty of TheOlogy
}

Book Title:

Anselm of Canterbury: The beauty of theology

\section{Book Cover:}

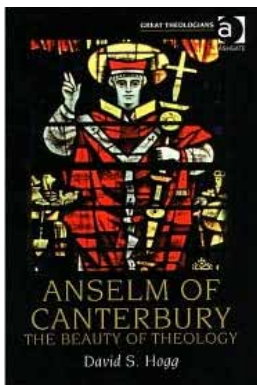

Author:

David S. Hogg

ISBN:

0-7546-3232-6

\section{Publisher:}

Ashgate Publishing Group, United Kingdom; 2004, p. 218, $£ 16.99 / £ 15.29$ *

*Book price at time of Review

Review Title:

The beauty of theology

Reviewer:

Jacobus P. Labuschagne ${ }^{1}$

\section{Affiliation: \\ ${ }^{1}$ Department of Church \\ History and Polity, \\ University of Pretoria, \\ South Africa}

\section{emails:}

kobus.labuschagne@up.ac.za natasha.felix@up.ac.za

\section{Postal address:}

PO Box 38046, Garsfontein-

East 0060, South Africa

\section{How to cite this book} review:

Labuschagne, J.P., 2010,

The beauty of theology

Verbum et Ecclesia 31(1), Art.

\#345, 2 pages. DOI: 10.4102/ ve.v31i1.345

\section{This review is available at: http://www.ve.org.za}

(c) 2010. The Authors. Licensee: OpenJournals Publishing. This work is licensed under the Creative Commons Attribution License.
David S. Hogg points out that although a lot of research work has already been done on Anselm's views concerning the existence of God and the atonement, the surrounding and indeed related areas have been left largely untouched. This discovery led Hogg to examine the works of Anselm on a much broader scale and then come to new conclusions. Hogg argues that there is a disadvantage in a too narrow focus on particular themes in Anselm's works; we run the risk of losing the real essence of Anselm's thinking when not taking the wider context into account. For example, Anselm's understanding of the atonement might not be rightly understood when we fail to look further and take an adequate account of his understanding of the Trinity. To this, Hogg adds that Anselm's interpretation of the Trinity, as it relates to the incarnation and atonement, is further explained and enhanced when we read the Proslogion. In the Proslogion Anselm not only attends to the existence of God, but also to the nature of God in whom all humans and all other things live and find their being. In the same way Hogg argues that the Cur Deus Homo can be best explained when this work is studied along with the Monologion (especially chapter 39 and following).

The common way of interpreting the Proslogion is to do it on the basis of the logical argument in chapters two, three and four, but what if the emphasis does not rightly lie there? Hogg works on the possibility of the revelation, outlined in chapter one and developed from there in chapters five to twenty-six, as the real basis for the argument in chapters two to four. Hogg comes to the conclusion that our contemporary convictions colour our comprehension of medieval concepts. He says that it is indeed typical of our contemporary mindset to prefer a logical argument that develops sequentially from one proposition to the next. Though medieval theological and philosophical thinking do sometimes develop in this way, Hogg finds evidence that for the medieval mind this was not the most desirable means of expressing an argument. Hogg discovers, as one characteristically medieval way of communicating truth and conviction, the explaining and development of ideas on the basis of an aesthetic ideal. For the medieval mind it is the presupposition of 'beauty and fittingness', as seen in the relationship between creator and creation, that provides the only foundation upon which our argument or series of propositions can be built. For Anselm and medieval thinking the basis of all our argumentation must be that there is something or indeed someone who holds everything together. And this is what Hogg wants to emphasise. Order and harmony and beauty, as guaranteed by the nature of God who created in his own image and sustains by his own power, is the needed precondition for medieval rational and logical thinking.

In his Cur Deus Homo Hogg discovers in Anselm an overarching principle of God as by nature the God of order, harmony and beauty, and that God necessarily acts in accordance to these aspects of his nature. He recognises in Anselm's thought as such an aesthetic dimension, which is a fully integrated part of creator and creation. Hogg found that many scholars, while aware of Anselm's aesthetic dimension, do not as yet fully realise that this aesthetic dimension is indeed inextricably interwoven in the whole of Anselm's thinking. This means then that when Anselm deals, for instance, with the subject of the atonement in his Cur Deus Homo, he is not merely interested in explaining a rational and objective view of the atonement. His point of departure remains the aesthetic dimension. Therefore, all goodness, beauty and order around us are the results of God's sustaining presence, God who in his uniqueness is the One, the Good and the Beautiful. Ugliness, wrong doings or disorder, are all deviations from the aesthetic dimension, and they are there because of sin. This, however, can be and indeed is rectified by God in his goodness. From this foundation follows Anselm's explanation of the atonement and the new creation effected by God.

Hogg found beauty and order as inherent in Anselm's perception of reality. Understandably Hogg discovered that this then holds good not only for the Cur Deus Homo, but also for Anselm's Monologion, his Proslogion, his Prayers and Meditations, and his De Incarnatione Verbi, also his De Grammatico, De Veritate, De Libertate Arbitrii, and De Casu Diaboli. For Anselm the person who seeks to understand something of God's revelation is also the person who will somehow find himself rejoicing in the experience of the divine, experiencing the depth and the mystery of God, and becoming aware of the beatific vision. The church has the task to let the whole of humanity hear about the atoning sacrifice of Christ and about reconciliation through renewal so that every human being may regain the beatific vision.

Hogg criticises Southern who refers to beauty in Anselm's prayers as overdoing it. Hogg is convinced that Anselm's prayers are not only intended to be beautiful, because they also bear witness to Anselm's perception of reality. Anselm's prayers are a manifestation of his existential awareness of the reality of the reconciliation achieved by Jesus Christ on the cross, and he hopes that also his readers will experience the same. The call of God, to be holy as he is holy, is so much alive in the mind of Anselm and he wishes to make his own all that God offers.

It is often said that Anselm has no central theme in his writings and that the subjects he wrote about were purely occasional. Hogg opposes this common view, by now not searching for a unity in the topics Anselm wrote about, but by discovering the weltbild (the hermeneutical framework, the particular understanding of reality) behind the thinking, as the real unifying factor. The weltbild, once discovered, without being repeatedly mentioned, nevertheless becomes conspicuous in the way Anselm said things and why he said them. The most pervasive element in his weltbild, which affects all 
of his thinking, bringing together particularity and diversity, is aesthetics. Hogg wishes to emphasise that Anselm indeed had an aesthetic model of reality in his mind. This understanding of reality was not uncommon in the literature of the world of which Anselm was part. This was an understanding of reality built upon the aesthetic view that all was wonderful, in harmony and unity, beauty and fittingness, attributes of God's being and attributes imprinted on the whole of creation and therefore also imprinted on man's way of reasoning, even the Christian's prayers and meditation.

Beauty is for Anselm indeed a multifaceted expression, and he can therefore even refer to the person and work of Christ as supreme beauty. 'Aesthetics' is for Hogg the all-embracing concept, including a wide range of issues connected to beauty. Hogg uses aesthetics as an explanatory concept, when describing Anselm's beatific vision. Hogg does this in spite of the fact that aesthetics was a term that came 650 years later than Anselm's time, originating from Baumgarten in the 18th century, and also in spite of a notably different direction taken by Baumgarten and Kant with the concept of aesthetics within the study of epistemology. He is convinced that even a cursory study of medieval literature would clearly indicate that aesthetic ideals influenced all thinking in the medieval mind. It is generally accepted that medieval theologians depended heavily on classical authors and the early church fathers. Hogg points out that Anselm more than once indicated his preference for Augustine, and Augustine also revealed his appreciation for aesthetic thinking.

Hogg hopes to provide a renewed appreciation for beauty and fittingness as foundational in Anselm's thinking, and to reveal that Anselm teaches us that the logic of human reason is not the only way of understanding God in his relation to man. Though we might today be hermeneutically far from the presuppositions of Anselm's mind, there is still a lot to be learned from his understanding and a lot to appreciate in his devotion.

The book offers a new insight into Anselm's thinking, and is a valuable and important contribution to the studies of medieval theologians. It is therefore recommended for theologians, students and ordinary Christians interested in medieval studies. 